ORNL/TM-2021/1917

TCR-RG-RPRT-006

\title{
TCR Postulated Accident and MHA Dose
}

\section{Assessment}

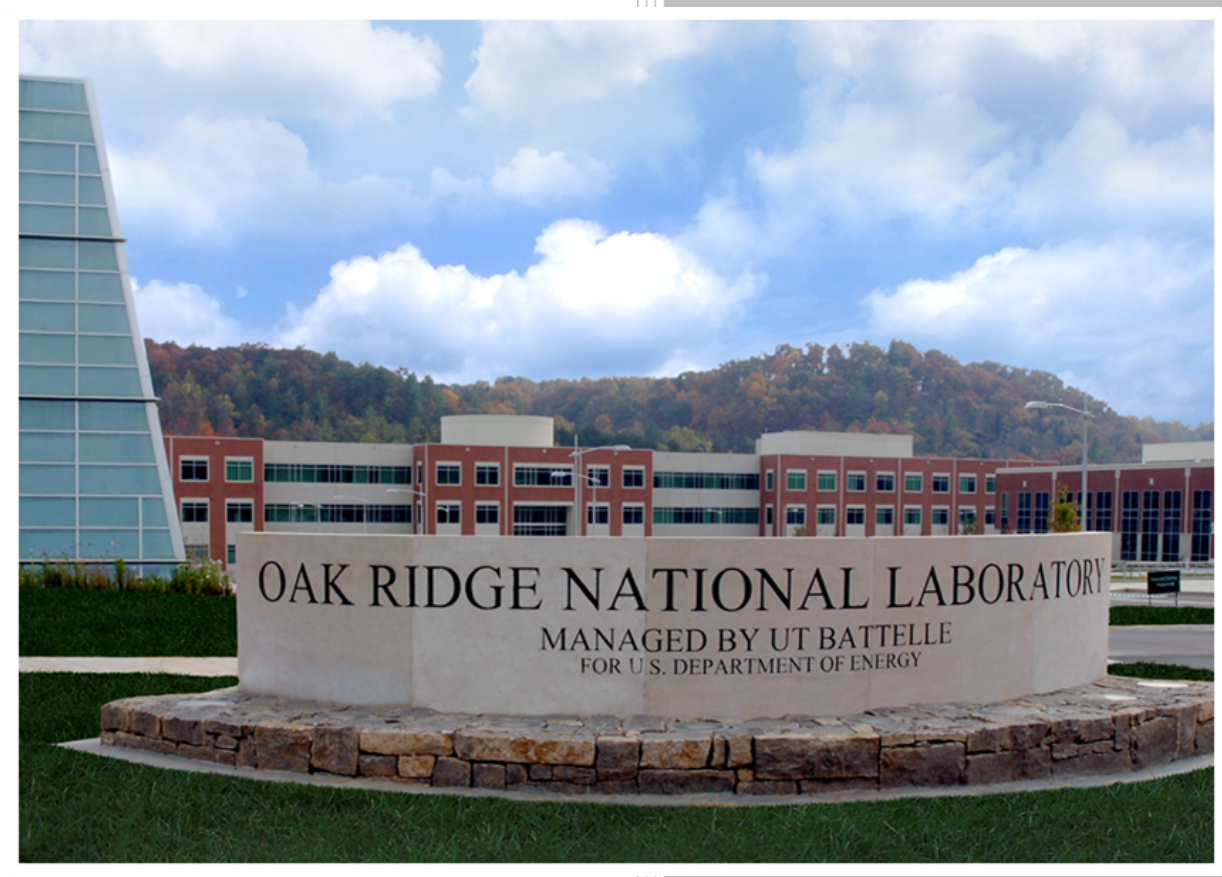

Approved for public release.

Distribution is unlimited.

H. Randall Fair

Alexander J. Huning

March 2021 


\title{
DOCUMENT AVAILABILITY
}

Reports produced after January 1, 1996, are generally available free via US Department of Energy (DOE) SciTech Connect.

Website www.osti.gov

Reports produced before January 1, 1996, may be purchased by members of the public from the following source:

\author{
National Technical Information Service \\ 5285 Port Royal Road \\ Springfield, VA 22161 \\ Telephone 703-605-6000 (1-800-553-6847) \\ TDD 703-487-4639 \\ Fax 703-605-6900 \\ E-mail info@ntis.gov \\ Website http://classic.ntis.gov/
}

Reports are available to DOE employees, DOE contractors, Energy Technology Data Exchange representatives, and International Nuclear Information System representatives from the following source:

Office of Scientific and Technical Information

PO Box 62

Oak Ridge, TN 37831

Telephone 865-576-8401

Fax 865-576-5728

E-mail reports@osti.gov

Website http://www.osti.gov/contact.html

This report was prepared as an account of work sponsored by an agency of the United States Government. Neither the United States Government nor any agency thereof, nor any of their employees, makes any warranty, express or implied, or assumes any legal liability or responsibility for the accuracy, completeness, or usefulness of any information, apparatus, product, or process disclosed, or represents that its use would not infringe privately owned rights. Reference herein to any specific commercial product, process, or service by trade name, trademark, manufacturer, or otherwise, does not necessarily constitute or imply its endorsement, recommendation, or favoring by the United States Government or any agency thereof. The views and opinions of authors expressed herein do not necessarily state or reflect those of the United States Government or any agency thereof. 


\title{
TCR POSTULATED ACCIDENT AND MHA DOSE ASSESSMENT
}

\author{
H. Randall Fair \\ Alexander J. Huning
}

March 2021

Prepared by OAK RIDGE NATIONAL LABORATORY

Oak Ridge, TN 37831-6283 managed by

UT-BATTELLE, LLC

for the

US DEPARTMENT OF ENERGY

under contract DE-AC05-00OR22725 



\section{CONTENTS}

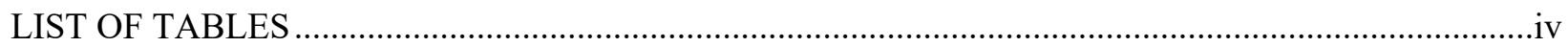

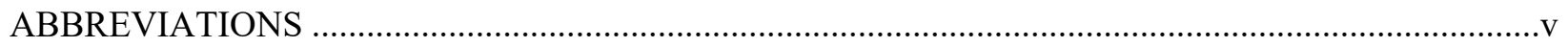

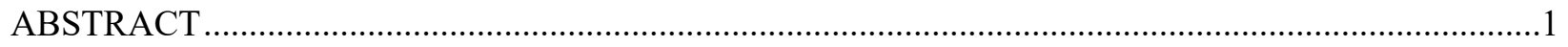

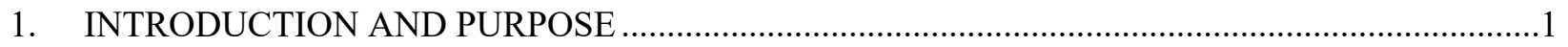

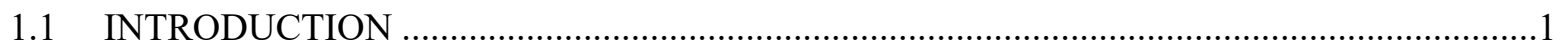

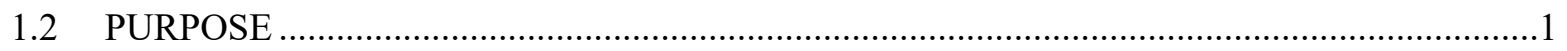

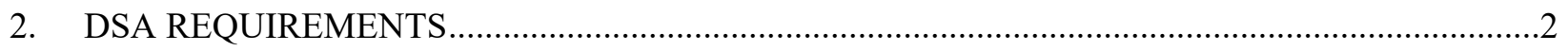

3. METHODOLOGY: SOURCE TERM INITIALIZATION AND DISPERSION

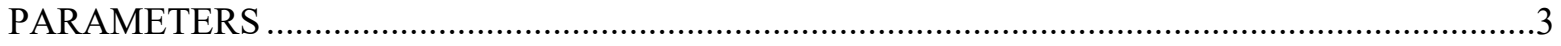

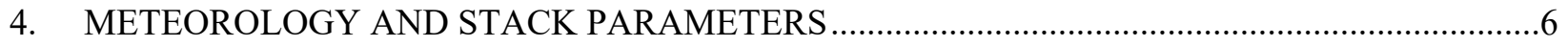

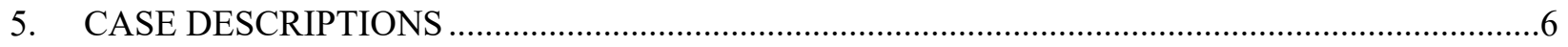

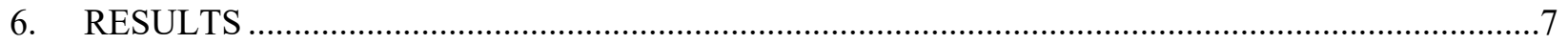

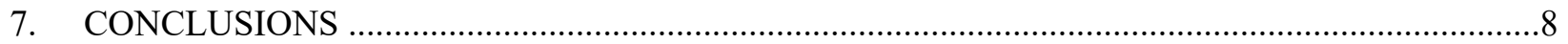

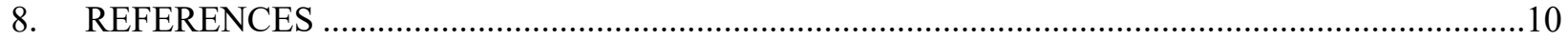




\section{LIST OF TABLES}

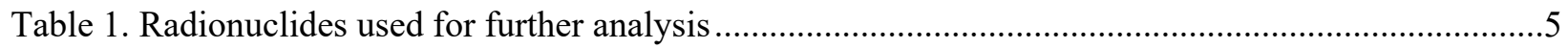

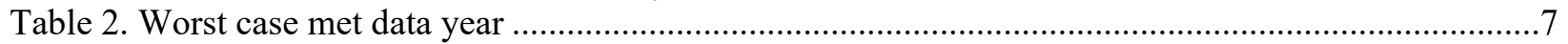

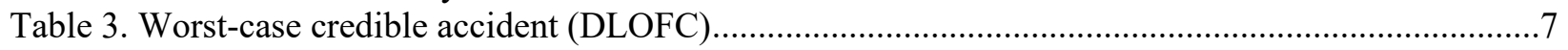

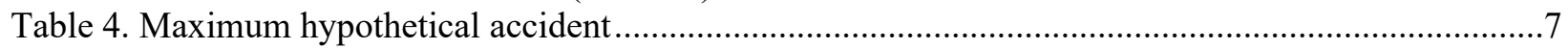

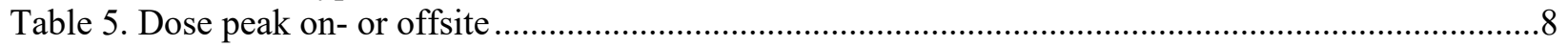

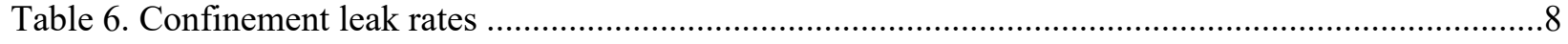


ABBREVIATIONS

CFR US Code of Federal Regulations

DLOFC depressurized loss of forced circulation

DOE US Department of Energy

DSA documented safety analysis

LLNL Lawrence Livermore National Laboratory

MHA maximum hypothetical accident

MOI

$\mathrm{NPH}$

ORNL

POC

QA

QAPP

RN

maximum-exposed offsite individual

natural phenomena hazard

Oak Ridge National Laboratory

point of contact

quality assurance

quality assurance project plan

SBMS

SQA

radionuclide

Standards-Based Management System

software quality assurance

TCR

Transformational Challenge Reactor

UT-B UT-Battelle, LLC 


\begin{abstract}
Oak Ridge National Laboratory (ORNL) is engaged in regulatory activities to gain US Department of Energy (DOE) approval to build and operate a small high-temperature gas reactor, the Transformational Challenge Reactor (TCR). ORNL uses advanced manufacturing techniques to produce select reactor components. The TCR is unique in its mission: the reactor's at-power operating lifetime will be less than one effective full-power day to limit the radiological source term to very low values, thus facilitating approval to operate. The primary regulatory documents governing construction and operation of the facility are NUREG-1537, "Guidelines for Preparing and Reviewing Applications for the Licensing of Non-Power Reactors" and DOE-STD-3009, "Preparation of Nonreactor Nuclear Facility Documented Safety Analysis."

Although this document is not a safety basis document, it provides a conservative indication of the magnitude of onsite and offsite radiological doses for specific scenarios, thus informing future design and regulatory activities. As required by NUREG-1537, scenarios included in this analysis are (1) a worstcase depressurized loss-of-forced-circulation accident, and (2) a maximum hypothetical accident. Details on the analysis of dose consequences with various system configurations are also provided.
\end{abstract}

\title{
1. INTRODUCTION AND PURPOSE
}

\subsection{INTRODUCTION}

The Transformational Challenge Reactor (TCR) is undergoing regulatory activities to obtain US Department of Energy (DOE) authorization to build and test advanced manufactured components in a nuclear reactor application at Oak Ridge National Laboratory (ORNL). Title 10 of the US Code of Federal Regulations (CFR) Part 830 lists Regulatory Guide 1.70 as the acceptable methodology for developing a documented safety analysis (DSA) for a reactor. Because this standard was developed specifically for light-water power reactors, TCR chose to adopt NUREG-1537, "Guidelines for Preparing and Reviewing Applications for the Licensing of Non-Power Reactors" [1], as the basis for developing the TCR DSA. The approach used in NUREG-1537 for bounding accidents is a maximum hypothetical accident (MHA). MHA scenarios are not required to be credible to account for uncertainties and to sufficiently bound the consequences from a purely deterministic perspective. This approach is preferred for simple, low-power, low-hazard type systems like research reactors and TCR.

The TCR MHA is a worst-case depressurized loss-of-forced-circulation accident. Fundamental safety functions such as core heat removal and reactivity control are still achieved for this hypothetical accident, but a larger-than-credible radionuclide release fraction from the fuel is assumed. This paper explores the requirements for radionuclide retention for the various barriers that TCR employs and the radiological dose to the workers and public during an MHA. Additionally, credible events are addressed for various system configurations to inform the design of TCR systems important to safety. TCR is expected to meet all dose threshold requirements specified in DOE-STD-3009, "Preparation of Nonreactor Nuclear Facility Documented Safety Analysis" [2].

\subsection{PURPOSE}

This document describes the process used to determine onsite and offsite radiological doses during offnormal radionuclide release situations and the results of those calculations. 


\section{DSA REQUIREMENTS}

The DSA requirements are as follows.

1. DOE-STD-3009 requires that an unmitigated consequence analysis be performed for plausible accident scenarios, natural phenomena hazard (NPH) events, and external events (i.e., not an MHA event). The standard also requires that the calculation of offsite dose be based on a non-buoyant, ground level, point source release. The stated intent is to provide a conservative estimate of the consequences to the facility worker, the co-located worker, and the maximum-exposed offsite individual (MOI) while assuming that mitigation controls do not perform their safety functions.

DOE-STD-3009 requirements for TCR are detailed below:

- The worst-case credible (or plausible) accident is a depressurized loss of forced circulation (DLOFC) with a failed fuel fraction of $1.50 \mathrm{E}-03$. This value is dependent on the number of fuel particles tested as part of the TCR irradiation campaign [3].

- The standard defines a facility worker as a worker within the facility boundary who is located less than 100 meters from the release point. There will be no workers present inside of or within 100 meters of the facility during any facility modes of operation that could result in a release. (This technical safety requirement will be an administrative control.)

- The standard defines a co-located worker as a worker at a distance of $100 \mathrm{~m}$ from a facility (building perimeter) or estimated release point. The distance from the edge of the proposed location of the TCR confinement to the control room is approximately $320 \mathrm{~m}$. The edge of the confinement structure was conservatively chosen as the perimeter/release point instead of the stack because the structure will not be leak tight. Distances from the stack to the control room and from the stack to the nearest offsite location exceed the distances from the edge of the structure. For the calculations described herein, a distance of 310 meters will be used.

- The MOI is defined in the standard as "an adult typically located at the point of maximum exposure on the DOE site boundary nearest to the facility in question (ground level release) or may be located at some farther distance where an elevated or buoyant radioactive plume is expected to cause the highest exposure (airborne release)." For TCR, this distance is $930 \mathrm{~m}$. (Figure 1).

2. NUREG-1537 [1] defines an MHA as a fission product release accident with radiological consequences that exceed those of any accident considered to be credible. Because the MHA is not expected to occur, the scenario does not need to be entirely credible. The initiating event and the scenario details do not require analysis, but the potential consequences should be analyzed and evaluated. The TCR MHA is considered to be a DLOFC with a failed fuel fraction of $1.50 \mathrm{E}-02$, which is a factor of 10 larger than that of the worst-case credible accident described above.

To address the possibility that an MOI may be located beyond $930 \mathrm{~m}$, due to plume and buoyancy effects, offsite doses will be computed at $1 \mathrm{~km}$ and further out to determine if the distance at which the peak dose occurs is onsite or offsite. 


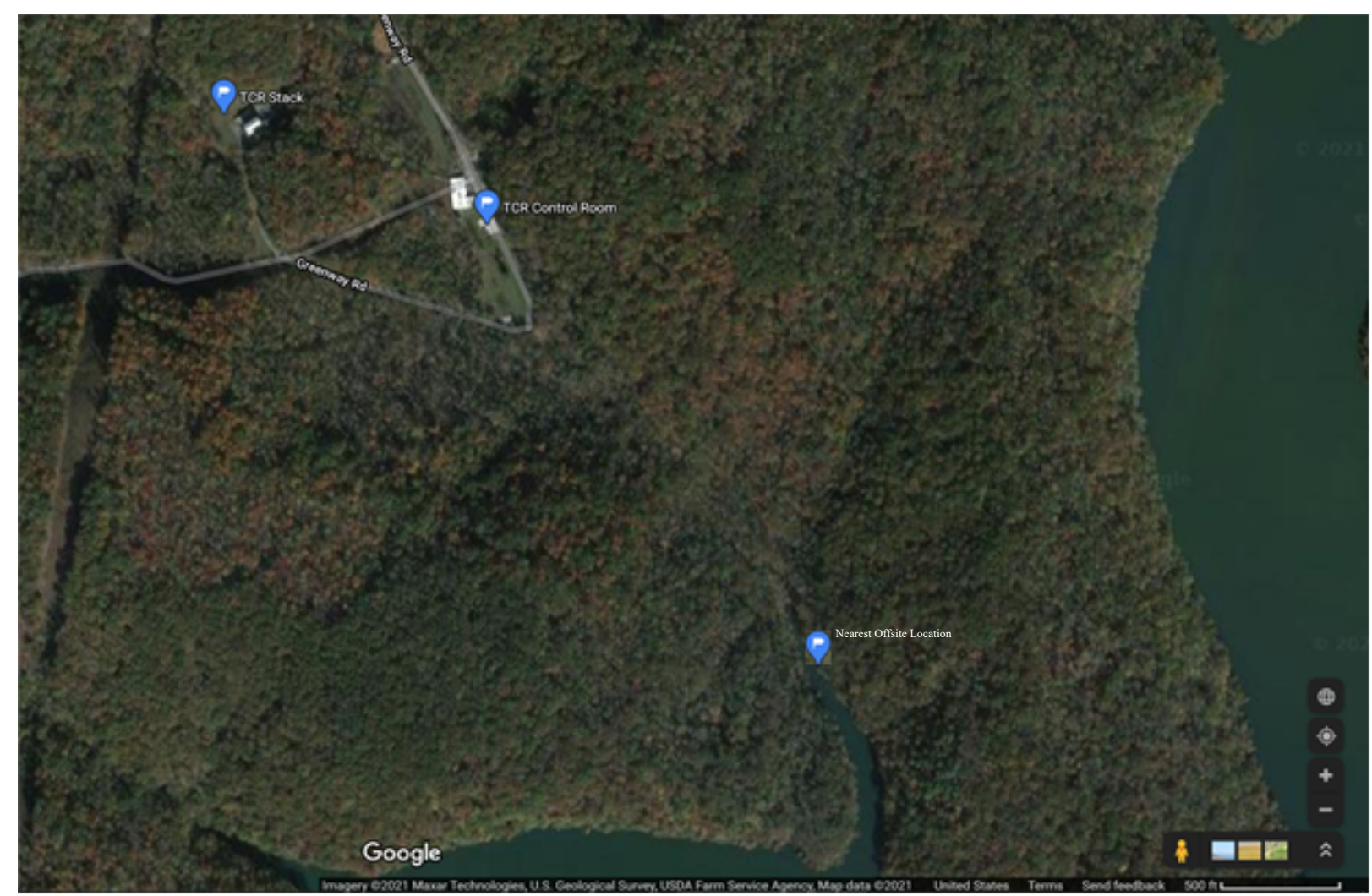

Figure 1. ORNL Proposed Location of TCR.

\section{METHODOLOGY: SOURCE TERM INITIALIZATION AND DISPERSION PARAMETERS}

All dose calculations in this report were performed using version 2.07.1 of the HotSpot Health Physics Codes, or HotSpot program, a DOE program developed by the Lawrence Livermore National Laboratory (LLNL) National Atmospheric Release Advisory Center. This program provides a first-order approximation of the radiation effects associated with the atmospheric release of radioactive materials using a Gaussian model based on distance, meteorological conditions, and the source term. Version 2.07.01 of this program is included in DOE's list of toolbox codes that have been evaluated against (1) the DOE safety software quality assurance requirements found in DOE O 414.1D, "Quality Assurance," and (2) the safety software guidance in DOE G 414.1-4, "Safety Software Guide," Appendix B, "Procedure for Adding or Revising Software to or Deleting Software from the DOE Safety Software Central Registry." DOE has accepted these as toolbox codes. Additional information on this program can be found in the HotSpot Health Physics Code User's Manual [4]. The stated use of the program is "for safety-analysis of Department of Energy (DOE) facilities handling nuclear material." The HotSpot atmospheric dispersion models are designed for near-surface releases, short-range (less than $10 \mathrm{~km}$ ) dispersion, and short-term (less than $24 \mathrm{~h}$ ) release durations in unobstructed terrain and simple meteorological conditions. These conditions fit TCR's configuration on the ORNL site. HotSpot includes a module that is used to calculate the $95^{\text {th }}$ percentile of the dose distribution for up to 20 radial centerline distances in each of 16 direction-dependent wind sectors and all 16 direction-independent wind sectors using historical meteorological data. The core inventory at the start of the release has been estimated assuming one continuous full power day of operation. The core will then be immediately shut down with all radionuclides (RNs) available for consideration during the release. The total number of unique RNs 
included in the core inventory is 1,675. This initial list of RNs was refined according to the steps below. Note that all of these steps are for the entire core contents; a credible damage ratio has not yet been applied at this point.

1. All radionuclides with values less than 1 microcurie and radionuclides not included in HotSpot were excluded. The initial list was reduced to 308 RNs.

2. HotSpot settings are as follows (these settings were also used for subsequent calculations):

- Deposition velocity was 0 for noble gases and 0.1 for all others.

- Airborne fraction, respirable fraction, and leak path factor were all set to 1.0.

- In selecting the "type" of exposure each radionuclide presented, the lethal dose table [5] was used. For each RN, the type showing the lowest activity that will produce a lethal dose was chosen.

- General plume was the dispersion model used. Other HotSpot models (plutonium/uranium fires, explosions, and resuspensions) are not applicable to TCR.

- Other parameters used are as follows:

- Terrain - standard/rural

○ Sample time - 10 minutes (default)

$\circ$ Wind input height $-15 \mathrm{~m}$ (reported height from meteorological data files)

○ Holdup time -0 min

- Nonrespirable deposition velocity $-8 \mathrm{~cm} / \mathrm{sec}$

○ Dose Conversion Factor (DCF) Library FGR 13

$\circ$ Breathing rate $-3.33 \mathrm{E}-04 \mathrm{~m}^{3} / \mathrm{s}$

- Ground shine with no weathering

○ Resuspension included (resuspension factor: NCRP Report No. 129)

Exposure duration -4 days

- Calculations for distances from the source included the following:

○ $0.03 \mathrm{~km}$ (contact dose)

○ $\quad 0.10 \mathrm{~km}$ (DOE STD-3009 assumed distance to co-located worker)

○ $0.31 \mathrm{~km}$ (actual distance from stack to the control room [distance to nearest actual co-located worker]) 
○ $0.93 \mathrm{~km}$ (shortest distance from stack to offsite locations)

3. Dose was then calculated for each of the $308 \mathrm{RNs}$ for a ground release.

4. The resulting list was sorted with decreasing dose at distance $0.03 \mathrm{~km}$ (contact dose). Percentage of total dose was then calculated for each RN and the accumulated dose recorded. The $85 \mathrm{RNs}$ responsible for the top $99.5 \%$ of the total calculated dose were used for further analysis (Table 1 ).

5. Two mix files were created for subsequent calculations.

Table 1. Radionuclides used for further analysis

\begin{tabular}{|c|c|c|}
\hline Isotope & Type & Curies \\
\hline ba-139 & S & $1.60 \mathrm{E}+05$ \\
\hline ba-140 & S & $8.20 \mathrm{E}+03$ \\
\hline ba-141 & F & $1.45 \mathrm{E}+05$ \\
\hline ba-142 & S & $1.43 \mathrm{E}+05$ \\
\hline br-84 & S & $2.38 \mathrm{E}+04$ \\
\hline ce-141 & S & $2.32 \mathrm{E}+03$ \\
\hline ce-143 & S & $5.82 \mathrm{E}+04$ \\
\hline ce-144 & S & $3.33 \mathrm{E}+02$ \\
\hline ce-145 & ND & $9.83 \mathrm{E}+04$ \\
\hline cs-138 & F & $1.67 \mathrm{E}+05$ \\
\hline cs-139 & ND & $1.56 \mathrm{E}+05$ \\
\hline cs-140 & ND & $1.43 \mathrm{E}+05$ \\
\hline $\mathrm{i}-131$ & V & $5.10 \mathrm{E}+03$ \\
\hline $\mathrm{i}-132$ & V & $1.87 \mathrm{E}+04$ \\
\hline $\mathrm{i}-133$ & V & $8.99 \mathrm{E}+04$ \\
\hline $\mathrm{i}-134$ & V & $1.96 \mathrm{E}+05$ \\
\hline i-135 & V & $1.45 \mathrm{E}+05$ \\
\hline kr-87 & $*$ & $6.33 \mathrm{E}+04$ \\
\hline kr-88 & $*$ & $8.79 \mathrm{E}+04$ \\
\hline kr-89 & $*$ & $1.12 \mathrm{E}+05$ \\
\hline la-140 & F & $1.54 \mathrm{E}+03$ \\
\hline la-141 & S & $1.44 \mathrm{E}+05$ \\
\hline la-142 & F & $1.46 \mathrm{E}+05$ \\
\hline la-143 & S & $1.47 \mathrm{E}+05$ \\
\hline mo-101 & S & $1.29 \mathrm{E}+05$ \\
\hline mo-99 & S & $3.40 \mathrm{E}+04$ \\
\hline nb-97 & F & $8.97 \mathrm{E}+04$ \\
\hline nb-98 & S & $1.44 \mathrm{E}+05$ \\
\hline nb-99m & ND & $6.03 \mathrm{E}+04$ \\
\hline Biologicl & bsoption \\
\hline
\end{tabular}

\begin{tabular}{|c|c|c|}
\hline Isotope & Type & Curies \\
\hline nd-147 & S & $3.40 \mathrm{E}+03$ \\
\hline nd-149 & F & $2.70 \mathrm{E}+04$ \\
\hline np-239 & S & $1.33 \mathrm{E}+05$ \\
\hline pm-149 & S & $6.66 \mathrm{E}+03$ \\
\hline pm-151 & S & $4.67 \mathrm{E}+03$ \\
\hline pr-143 & S & $1.56 \mathrm{E}+03$ \\
\hline pr-145 & S & $9.18 \mathrm{E}+04$ \\
\hline pr-146 & ND & $7.51 \mathrm{E}+04$ \\
\hline pr-147 & F & $5.51 \mathrm{E}+04$ \\
\hline pr-148 & ND & $4.11 \mathrm{E}+04$ \\
\hline rb-88 & F & $8.84 \mathrm{E}+04$ \\
\hline rb-89 & F & $1.10 \mathrm{E}+05$ \\
\hline rb-90 & ND & $1.20 \mathrm{E}+05$ \\
\hline rb-90m & ND & $2.19 \mathrm{E}+04$ \\
\hline rh-105 & S & $7.31 \mathrm{E}+03$ \\
\hline ru-103 & V & $1.35 \mathrm{E}+03$ \\
\hline ru-105 & V & $2.49 \mathrm{E}+04$ \\
\hline sb-127 & S & $6.16 \mathrm{E}+02$ \\
\hline sb-128 & F & $4.75 \mathrm{E}+02$ \\
\hline sb-128m & F & $8.57 \mathrm{E}+03$ \\
\hline sb-129 & F & $1.35 \mathrm{E}+04$ \\
\hline sb-130 & F & $1.81 \mathrm{E}+04$ \\
\hline sb-130m & ND & $2.56 \mathrm{E}+04$ \\
\hline sb-131 & F & $6.41 \mathrm{E}+04$ \\
\hline sb-133 & ND & $5.33 \mathrm{E}+04$ \\
\hline se-83 & F & $1.14 \mathrm{E}+04$ \\
\hline sn-127 & F & $2.43 \mathrm{E}+03$ \\
\hline sn-128 & F & $8.41 \mathrm{E}+03$ \\
\hline sn-130 & ND & $1.56 \mathrm{E}+04$ \\
\hline ND No & Dta) \\
\hline
\end{tabular}

\begin{tabular}{|c|c|c|}
\hline Isotope & Type & Curies \\
\hline sr-89 & S & $1.58 \mathrm{E}+03$ \\
\hline sr-91 & S & $1.19 \mathrm{E}+05$ \\
\hline sr-92 & F & $1.48 \mathrm{E}+05$ \\
\hline sr-93 & ND & $1.55 \mathrm{E}+05$ \\
\hline sr-94 & ND & $1.51 \mathrm{E}+05$ \\
\hline tc-101 & F & $1.30 \mathrm{E}+05$ \\
\hline tc-104 & F & $4.76 \mathrm{E}+04$ \\
\hline tc-105 & ND & $2.50 \mathrm{E}+04$ \\
\hline tc-99m & F & $2.03 \mathrm{E}+04$ \\
\hline te-131 & V & $6.32 \mathrm{E}+04$ \\
\hline te-131m & V & $4.03 \mathrm{E}+03$ \\
\hline te-132 & V & $2.10 \mathrm{E}+04$ \\
\hline te-133 & V & $8.21 \mathrm{E}+04$ \\
\hline te-133m & V & $9.35 \mathrm{E}+04$ \\
\hline te-134 & V & $1.74 \mathrm{E}+05$ \\
\hline $\mathrm{u}-239$ & S & $5.34 \mathrm{E}+05$ \\
\hline $\mathrm{xe}-135$ & $*$ & $9.64 \mathrm{E}+04$ \\
\hline $\mathrm{xe}-137$ & $*$ & $1.52 \mathrm{E}+05$ \\
\hline $\mathrm{xe}-138$ & $*$ & $1.57 \mathrm{E}+05$ \\
\hline $\mathrm{y}-91$ & S & $8.55 \mathrm{E}+02$ \\
\hline y-91m & F & $6.87 \mathrm{E}+04$ \\
\hline y-92 & S & $1.45 \mathrm{E}+05$ \\
\hline y-93 & S & $1.27 \mathrm{E}+05$ \\
\hline y-94 & F & $1.57 \mathrm{E}+05$ \\
\hline$y-95$ & F & $1.57 \mathrm{E}+05$ \\
\hline zr-95 & S & $1.73 \mathrm{E}+03$ \\
\hline zr-97 & S & $9.41 \mathrm{E}+04$ \\
\hline
\end{tabular}

Biological absorption rate types: ND (No Data), F (Fast), S (Slow), V (Vapor), * (Noble Gas), 


\section{METEOROLOGY AND STACK PARAMETERS}

The release parameters are as follows:

- Release height: zero for ground releases cases

- Release height: $27.7 \mathrm{~m}$ for stack release cases, with the following plume rise parameters:

○ Air temperature: $38^{\circ} \mathrm{C}$

○ Velocity: $11.29 \mathrm{~m} / \mathrm{s}$

- Effluent temperature: $196^{\circ} \mathrm{C}$

○ Stack diameter: $2.44 \mathrm{~m}$

The site meteorological data are as follows:

- Met data for years 2015-2019 were provided at https://metweb.ornl.gov. A stack calculation of dose using one of the mix files was performed for each year.

- Data for 2017 were determined to yield the highest dose onsite. There was no significant difference in offsite dose when compared with any of the data files (Table 2).

\section{CASE DESCRIPTIONS}

Two mix files were created for the 85 RNs (HotSpot mix files have a limitation of 50 items). Using the two mix files, the following calculations were performed:

1. For the worst-case credible accident (DLOFC), the damage ratio was set to $1.50 \mathrm{E}-03$.

Two calculations were performed: one for a ground-level release, and the other for an elevated release out of the stack. No filtration was assumed. The calculations included distances of $0.10,0.31$, and $0.93 \mathrm{~km}$, as stated above.

Beyond-site boundary calculations were performed for both ground-level and stack releases to determine whether the peak dose remained onsite.

2. For the MHA, the damage ratio was set to $1.50 \mathrm{E}-02$.

Both ground-level and stack releases were calculated.

3. Calculations were performed at distances of 1.0 and $1.5 \mathrm{~km}$, in addition to $0.93 \mathrm{~km}$, to determine whether the peak dose was onsite or offsite.

4. A confinement design sensitivity study was performed to investigate the impact of varying confinement leakage rates. 


\section{RESULTS}

As can be seen from the tables below, using 2017 met data provides the most conservative results.

Table 2. Worst case met data year

\begin{tabular}{|c|c|c|}
\hline Year & $\begin{array}{c}\text { Ground } \\
\text { release (rem) } \\
\mathbf{0 . 3 1} \text { km from } \\
\text { source }\end{array}$ & $\begin{array}{c}\text { Ground } \\
\text { release (rem) } \\
\mathbf{0 . 9 3 ~ k m ~ f r o m ~} \\
\text { source }\end{array}$ \\
\hline 2015 & $2.90 \mathrm{E}+01$ & $2.66 \mathrm{E}+00$ \\
\hline 2016 & $2.91 \mathrm{E}+01$ & $2.69 \mathrm{E}+00$ \\
\hline 2017 & $2.88 \mathrm{E}+01$ & $2.69 \mathrm{E}+00$ \\
\hline 2018 & $2.93 \mathrm{E}+01$ & $2.69 \mathrm{E}+00$ \\
\hline 2019 & $2.91 \mathrm{E}+01$ & $2.69 \mathrm{E}+00$ \\
\hline
\end{tabular}

\begin{tabular}{|c|c|c|}
\hline Year & $\begin{array}{c}\text { Stack release } \\
\mathbf{0 . 3 1} \mathbf{~ k m} \text { from } \\
\text { source (km) }\end{array}$ & $\begin{array}{c}\text { Stack release } \\
\text { (rem) } \mathbf{0 . 9 3} \mathbf{~ k m} \\
\text { from source }\end{array}$ \\
\hline 2015 & $8.36 \mathrm{E}-07$ & $5.00 \mathrm{E}-03$ \\
\hline 2016 & $4.77 \mathrm{E}-05$ & $5.48 \mathrm{E}-03$ \\
\hline $\mathbf{2 0 1 7}$ & $\mathbf{2 . 0 4 E - 0 4}$ & $\mathbf{6 . 3 6 E - 0 3}$ \\
\hline 2018 & $3.62 \mathrm{E}-06$ & $5.22 \mathrm{E}-03$ \\
\hline 2019 & 7.17E-06 & $5.27 \mathrm{E}-03$ \\
\hline
\end{tabular}

Table 3. Worst-case credible accident (DLOFC)

Ground Release

\begin{tabular}{|c|c|}
\hline $\begin{array}{c}\text { Distance from } \\
\text { source (km) }\end{array}$ & Dose (rem) \\
\hline 0.100 & $3.80 \mathrm{E}+02$ \\
\hline 0.310 & $4.27 \mathrm{E}+01$ \\
\hline 0.930 & $3.90 \mathrm{E}+00$ \\
\hline
\end{tabular}

Stack Release

\begin{tabular}{|c|c|}
\hline $\begin{array}{c}\text { Distance from } \\
\text { source (km) }\end{array}$ & Dose (rem) \\
\hline 0.100 & $0.00 \mathrm{E}+00$ \\
\hline 0.310 & $3.15 \mathrm{E}-04$ \\
\hline 0.930 & $9.74 \mathrm{E}-03$ \\
\hline
\end{tabular}

Table 4. Maximum hypothetical accident

Ground Release

\begin{tabular}{|c|c|}
\hline $\begin{array}{c}\text { Distance from } \\
\text { source (km) }\end{array}$ & Dose (rem) \\
\hline 0.100 & $3.80 \mathrm{E}+03$ \\
\hline 0.310 & $4.27 \mathrm{E}+02$ \\
\hline 0.930 & $3.90 \mathrm{E}+01$ \\
\hline
\end{tabular}

Stack Release

\begin{tabular}{|c|c|}
\hline $\begin{array}{c}\text { Distance from } \\
\text { source (km) }\end{array}$ & Dose (rem) \\
\hline 0.100 & $0.00 \mathrm{E}+00$ \\
\hline 0.310 & $3.15 \mathrm{E}-03$ \\
\hline 0.930 & $9.74 \mathrm{E}-02$ \\
\hline
\end{tabular}

Maximum dose occurs onsite as demonstrated by the results below for a DLOFC release. 
Table 5. Dose peak on- or offsite for a DLOFC release

Ground Release

\begin{tabular}{|c|c|}
\hline $\begin{array}{c}\text { Distance from } \\
\text { source (km) }\end{array}$ & Dose (rem) \\
\hline 0.93 & $3.90 \mathrm{E}+00$ \\
\hline 1.00 & $3.35 \mathrm{E}+00$ \\
\hline 1.50 & $1.42 \mathrm{E}+00$ \\
\hline
\end{tabular}

Stack Release

\begin{tabular}{|c|c|}
\hline $\begin{array}{c}\text { Distance from } \\
\text { source (km) }\end{array}$ & Dose (rem) \\
\hline 0.93 & $9.74 \mathrm{E}-03$ \\
\hline 1.00 & $9.60 \mathrm{E}-03$ \\
\hline 1.50 & $8.22 \mathrm{E}-03$ \\
\hline
\end{tabular}

Using the tables for ground release and stack release above, various ground-level and stack releases were combined to estimate dose consequences for varying confinement leak rates as seen in the Table 6 .

Table 6. Confinement leak rates

\begin{tabular}{|c|c|c|c|}
\hline & \multicolumn{3}{|c|}{ Total Dose (rem) } \\
\hline Leak rate (\%) & $\mathbf{0 . 1 0 0} \mathbf{~ k m}$ & $\mathbf{0 . 3 1 0} \mathbf{~ k m}$ & $\mathbf{0 . 9 3} \mathbf{~ k m}$ \\
\hline $0 \%$ & 0 & 0 & 0 \\
\hline $5 \%$ & 19 & 2 & 0 \\
\hline $10 \%$ & 38 & 4 & 0 \\
\hline $15 \%$ & 57 & 6 & 1 \\
\hline $20 \%$ & 76 & 9 & 1 \\
\hline $25 \%$ & 95 & 11 & 1 \\
\hline $26 \%$ & 99 & 11 & 1 \\
\hline $32 \%$ & 103 & 12 & 1 \\
\hline
\end{tabular}

\section{CONCLUSIONS}

The following conclusions were made.

- Since the worst-case credible accident (DLOFC) results in an offsite dose of 3.9 rem (ground release) and 0.01 rem (stack release), no safety class or safety significant equipment is required to protect the public (Table 3).

- If $100 \mathrm{~m}$ is used for the co-located worker distance, then the DLOFC dose to the co-located workers is $380 \mathrm{rem}$, resulting in a requirement for safety-significant equipment to mitigate dose to workers to below 100 rem.

- If the DSA justifies use of the actual distance $(310 \mathrm{~m})$ to the workers, then the worst-case credible accident results in a dose of 43 rem, which would require no safety-significant equipment to protect co-located workers. 
- Ground-level and stack release values for the TCR MHA were presented in Table 4.

- The maximum dose from the maximum credible accident (DLOFC) will occur onsite (Table 5) for either a ground release or a stack release.

- If $100 \mathrm{~m}$ is used for the co-located worker distance, then confinement leakage must be kept below approximately $26 \%$, which is the value resulting in $\geq 100$ rem onsite dose. If $310 \mathrm{~m}$ is used for colocated workers, then there are no safety significant restrictions on confinement leakage. 


\section{REFERENCES}

[1] US Nuclear Regulatory Commission, "Guidelines for Preparing and Reviewing Applications for the Licensing of Non-Power Reactors," NUREG-1537, 1996.

[2] US Department of Energy, "Preparation of Nonreactor Nuclear Facility Documented Safety Analysis," DOE-STD-3009, 2014.

[3] Huning, A. J., W. M. Kirkland, and K. A. Terrani, “Transformational Challenge Reactor Safety Design and Radionuclide Retention Strategy," (in preparation).

[4] Lawrence Livermore National Laboratory, "HotSpot Health Physics Codes User's Guide," V2.07.1, 2010.

[5] Sandia National Laboratories, "Lethal Dose Screening Thresholds for Sabotage Analysis: Technical Basis,” SAND2020-3772, 2020.

[6] Oak Ridge National Laboratory, "Oak Ridge Reservation Meteorology Environmental Modeling Input," https://metweb.ornl.gov/page6.htm, accessed March 4, 2021. 